\title{
The Names of Himalayan Peaks
}

\section{Author(s): A. M. Kellas}

Source: The Geographical Journal, Vol. 53, No. 5 (May, 1919), p. 358

Published by: geographicalj

Stable URL: http://www.jstor.org/stable/1779490

Accessed: 11-05-2016 11:31 UTC

\section{Your use of the JSTOR archive indicates your acceptance of the Terms \& Conditions of Use, available at}

http://about.jstor.org/terms

JSTOR is a not-for-profit service that helps scholars, researchers, and students discover, use, and build upon a wide range of content in a trusted digital archive. We use information technology and tools to increase productivity and facilitate new forms of scholarship. For more information about JSTOR, please contact support@jstor.org.

The Royal Geographical Society (with the Institute of British Geographers), Wiley are collaborating with JSTOR to digitize, preserve and extend access to The Geographical Journal 
on March 26 the Council were represented by Sir Maurice de Bunsen and Colonel Sir Henry McMahon.

\section{CORRESPONDENCE}

\section{The South Magnetic Pole.}

As an observer who has carried out in the past a very large number of magnetic observations in Antarctic latitudes and as a student still of terrestrial magnetism, I have read with considerable interest Mr. E. A. Reeves' ingenious paper appearing in last month's Fournal on "A Transformation of the Magnetic Dip Chart" and the discussion in connection therewith. In the report of the discussion on page ${ }^{6} 64 \mathrm{Mr}$. Hinks states, no doubt inadvertently, that Professor David had fixed the position of the south magnetic pole to within a few miles, and that he had some claim to be considered as an authority as "he is the only man who has made observations near it" (the magnetic pole). I think this statement is liable to be a little misleading.

Professor David, as we know, is a very eminent geologist, and he was probably in command of the small sledge party (Sir Ernest Shackleton's Antarctic Expedition) which set out towards the assumed direction of the south magnetic pole, but Douglas Mawson was the physicist of the party and the actual observer who carried out a series of magnetic observations near or in the approximate area of the south magnetic pole.

\section{Admiralty, I8 March 1919.}

L. C. BERNACCHI.

I am obliged to Lieut.-Commander Bernacchi for calling attention to the slip which I made in the discussion of Mr. Reeves' paper. Not only was Sir Douglas Mawson the magnetic observer with Professor David's party on the Shackleton expedition, but on his own expedition in I9II-I3 a further important contribution to the determination of the south magnetic pole was made by a sledge party in charge of Mr. Kidson, with Mr. Eric Webb as magnetic observer; and this should also have been mentioned.

A. R, H.

\section{The Names of Himalayan Peaks.}

Colonel Wauhope's letter is of considerable value as a contribution to the above problem, but one trusts that the names of the first and second mountains on the world's surface as regards altitude, will be reconsidered within the next few years, before a final decision is reached.

The name "Kinchenjunga," given by Colonel Wauhope, is an improvement on the Kinchinjunga appearing on maps after 1906, but in 1903 the name Kanchenjunga was used, so that the etymology has been obscured comparatively recently. Perhaps one might point out that Kang is the spelling of the Tibetan word for snow given by Mr. C. A. Bell, I.C.S., one of the best known British authorities on the language, but if "Gang" is more correct, it might be considered.

As regards Mount Everest, one ventures to hope that the name will not be definitely fixed until after the exploration of the group of mountains of which it is chief.

A. M. KELtaAs,

7 April r9r9. 